\title{
Transpiration in 15 Tree Species Grown on a Phytocapped Landfill Site Kartik Venkatraman $^{1^{*}}$ and Nanjappa Ashwath ${ }^{2}$
}

${ }^{1}$ East Gippsland Shire Council, 273 Main Street, Bairnsdale, Victoria 3875, Australia

${ }^{2}$ School of Medical and Applied Science, CQUniversity, Rockhampton, QId 4702, Australia

*Corresponding author: Kartik Venkatraman, East Gippsland Shire Council, 273 Main Street, Bairnsdale, Victoria 3875 , Australia, Tel: 03 5153 9500; E-mail: kartikv@egipps.vic.gov.au

Rec date: Feb 26, 2016; Acc date: Apr 18, 2016; Pub date: Apr 24, 2016

Copyright: () 2016 Venkatraman K, et al. This is an open-access article distributed under the terms of the Creative Commons Attribution License, which permits unrestricted use, distribution, and reproduction in any medium, provided the original author and source are credited.

\begin{abstract}
An alternative landfill capping technique 'Phytocapping' (establishing plants on a layer of soil placed over the waste) was trialled at Rockhampton, Australia. In this capping trees act as 'bio-pumps and 'rain interceptors' and soil cover as 'storage'. They together minimise water percolation leading to reduced leachate production. "Transpiration" is a vital process to maintain the hydrological balance of a particular site. To be successful, the trees must transpire enough water from the soil so as to reduce water percolation through the refuse. Water uptake in trees is influenced by plant growth, tree characteristics, root activities, soil depth, soil water availability as well as climatic conditions (rainfall intensity, wind velocity, relative humidity and temperature). The potential of the tree species to remove water from the system plays a vital role in the sustainability of phytocapping system. Currently very little information is available on water uptake patterns of native species established on landfill sites. Results from this study suggest that the tree species grown on a phytocap are able to take up to $2.1 \mathrm{~mm}^{-1} \mathrm{y}^{-1}$ of water with an average of $1.4 \mathrm{~mm}^{-1}$.
\end{abstract}

Keywords: Landfills; Native species; Phytocaps; TDP sensor; Dynagauge transpiration

\section{Introduction}

An understanding of the movement of water from the soil to the atmosphere via trees is important with regard to phytocaps, as trees grown on phytocaps make a significant contribution to the hydrological balance of the site on which these are grown. Trees primarily help restrict rainwater entering the buried waste via canopy interception and transpiration. This Paper discusses the role played by different tree species.

Transpiration is the amount of water taken up (upward movement) by a plant for its own use, with the excess being released into the atmosphere, and is one of the key processes that helps maintain the hydrological balance of a site [1]. For Phytocapping to be effective, the plants must transpire sufficient water so as to reduce its percolation into the waste [2]. Trees generally transpire water during the day as part of photosynthesis [3]. The transpiration rates vary between species due to variation in stomatal density and climatic conditions [4]. Transpiration has been expressed in a number of ways and most scientists and hydrologists express transpiration as $\mathrm{mm} \mathrm{d}^{-1}[3]$, as this takes into consideration the area covered by the tree.

Sunlight is the main source of energy for trees to transpire, as this process involves the flow of water against gravity [3]. The amount of solar radiation incident on top of a canopy varies from the minimum (or zero) in the night to a maximum at noon. The transpiration rate and rate of evaporation would be expected to follow the same pattern. However, this is not the case due to "the resistance to water flow that exists between soil and leaf" [3]. The presence of this resistance results in a time lag between increasing transpiration and increasing rates of water uptake by the roots. In most cases, transpiration increases as the sun rises and decreases by late afternoon, as the sun starts setting. However, resistance in the xylem and leaves does not allow transpiration to take place in the early part of the day in many instances, and it increases during the latter part of the day [3].

Night time transpiration of $0.8 \mathrm{~mm}$ was recorded by Benyon [5] during a study at Wagga Wagga (NSW), and this could make a significant contribution to the overall water use of the trees especially during dry season. TDP sensors do not record night transpiration. There are numerous reports of water loss at night. Sapflow measurements indicate that night time loss ranges from 5 to $30 \%$ of daily water loss in Actinidia, Eucalyptus, Malus, Populus, Prosopis, Salix, Taxodium, and Dipterocarp [5-10]. For example Arabidopsis, Betula, Brassica, Chrysothamnus, Fraxinus, Picea, Rosa, Tarcobatus and Tilia have substantial night time water loss [11-13]. Seasonal changes contribute to the change in transpiration rates. Dye [14] reported an average uptake of $30 \mathrm{~L} \mathrm{~d}^{-1}$ during winter and around $90 \mathrm{~L}$ $\mathrm{d}^{-1}$ during peak summers by a $E$. grandis tree that was $14.7 \mathrm{~m}$ tall with a diameter of $147 \mathrm{~mm}$. Kalma et al. [15] reported an average consumption of $14.5 \mathrm{~L} \mathrm{~d}^{-1}$ and $10 \mathrm{~L} \mathrm{~d}^{-1}$ in a five year-old $E$. grandis trees in Toolara, near Brisbane, which had a height of $12.8 \mathrm{~m}$ and 12.9 $\mathrm{m}$ respectively. Similar findings were reported by Dye [14] for an $E$. grandis tree and Soares and Almedia [16] for a eucalyptus plantation in Brazil. They reported $1.1 \mathrm{~mm} \mathrm{~d}^{-1}$ to $8 \mathrm{~mm} \mathrm{~d}^{-1}$ (9 year-old), $4 \mathrm{~mm} \mathrm{~d}^{-1}$ (5 years-old) and $2 \mathrm{~mm} \mathrm{~d}^{-1}$ to $4 \mathrm{~mm} \mathrm{~d}^{-1}$ (9 year-old) respectively. Benyon [17] predicted $1 \mathrm{~mm} \mathrm{~d}^{-1}$ to $2 \mathrm{~mm} \mathrm{~d}^{-1}$ of water consumed by $E$. grandis under well-watered conditions.

Leaf temperature, a function of the amount of solar radiation received by the leaf, also affects transpiration rates [3]. Leaf temperature increases with leaf size [3]. For example, casuarinas, which have needle, shaped leaves, show very small surface areas as compared to broad leaved species (such as eucalypts). Transpiration rates decrease with a reduction in soil temperature from $45^{\circ} \mathrm{C}$ to $11^{\circ} \mathrm{C}$ [18]. Transpiration rates of whole plants are also influenced by the soil moisture potential [19], the extent of soil volume explored by the root system [20], the architecture of the tree [21], and anatomical and physiological features of the tree [22]. Transpiration rates vary among 
species [23], season [17], soil water availability, leaf area [24], leaf biomass [25], climatic conditions, root development, the age of plantation [26] and geographical region [4]. It is also influenced by shallow water tables [27]. Various studies have shown that transpiration rates of different trees are largely influenced by LAI [3]. Transpiration is also influenced by an increase in stem diameter at DBH and root growth [3].

The ability of plants to acquire water depends on root distribution [28] which also depends on the above ground responses of plants such as leaf area and leaf biomass [24]. Tree roots respond quickly to rain [29] and the degree to which lateral roots influence water uptake may relate to the availability of water in the soil [30]. At first, the trees may use the rainwater stored in the upper profile of the soil, followed by streams adjacent to the site, and lastly the available groundwater [3].

Water uptake in any system can be determined by methods based on pan evaporation and the Penman-Monteith equation [31], soilwater balance [32], lysimeters [33], portable gas exchange chambers [34] and heat pulse methods [35]. However, sapflow and sap velocity have been extensively used by researchers, scientists and engineers [36] and the values are comparable to those of other methods of estimating transpiration, such as the heat pulse method [37]. The Thermal Dissipation Probes (TDP) $[6,38]$ developed by Granier in the 1980 s [37] require careful installation of the sensors within the sapwood while avoiding the heart wood [39].

In the TDP method, the xylem sap is heated continuously; unlike in the heat pulse method where heat is applied as a pulse at regular intervals (typically 1 to 100 seconds; depending on the temperature of the sap) [40] Burgess et al. [41] further developed an improved heat pulse technique known as the Heat Ratio Method (HRM) to measure low and inverse transpiration rates in woody plants. This method can quantify low levels of transpiration as well as night time transpiration in woody plants. This method also allows monitoring of water flows in stems and roots of a wide range of species and stem sizes under varied environmental conditions.

In the Heat Balance Method (HBM) or Dynagauges), sensors are generally wrapped around the stem [42] and a small quantity of heat is applied continuously to raise the temperature of the stem [43]. This method has been successfully adopted by Sakuratani, Velancogne and Nasr, Weibel and Vos [44-46]. The commercial version of the Dynagauges [43] (Dynamax, Inc, Houston Texas, USA) was used in this study, with a few dynagauges and HRM probes used for comparison.

A TDP sensor consists of two needles that are inserted into the sapwood of the tree at a fixed distance of $40 \mathrm{~mm}$ between the two needles. A copper constantan thermocouple is located within each needle at half way or $15 \mathrm{~mm}$ from the base of each needle. The needles have a Teflon coating to assist in the removal from the stem. The needles are usually inserted into the stem at around $1 \mathrm{~m}$ height. One needle is inserted at the lower position (reference needle) and the other at the upper position. The upper needle contains a fixed line heater that is constantly heated. When the sapflow occurs, the heat produced by the upper needle will be diluted by the sapflow. When this occurs the upper needle produces more heat as it tries to maintain constant temperature. Thus, the current required to maintain a pre-determined heat will be measured and this will be correlated with sapflow, after correcting for the sapwood volume.

The HRM sensor consists of three $30 \mathrm{~mm}$ long needles (probes) integrally connected to a 16-bit microprocessor. The top and bottom probes each contain a set of two very fine copper constantan thermocouples placed at $7.5 \mathrm{~mm}$ and $22.5 \mathrm{~mm}$ from the tip of each probe. The third and centrally located probe is a line heater that runs the full length of the probe to deliver a uniform pulse of heat through the sapwood. In the HRM technique, three probes are inserted into the sap wood, such that the middle probe releases a pulse of heat, and the probes located above and below will record the heat dissipated from the central probe. Thus, the ratio of the heat dissipated from the central probe to the two symmetrically placed temperature sensors will determine the magnitude and direction of water flux. The rate of dissipation of heat is proportional to the rate of sapflow and this will be corrected for sapwood volume, and expressed in $\mathrm{mm}$ per tree per day. The raw data were imported to an excel spreadsheet and the sap velocity readings from individual trees were multiplied by the sapwood area of each tree to obtain sapflow in $\mathrm{mm} \mathrm{d}-1$. Wounding coefficient is the value derived from the finite element model to determine the effect of wounding on sap velocity [41].

The TDP and HRM techniques are automated [47], moderately invasive [48] and are widely used in transpiration and water relations studies of woody plants [49]. The TDP technique was developed to overcome limitations encountered by dynagauges in measuring radial profiles of sapflow in large diameter woody trees having deeper layers of sapwood [39]. Sapwood depth varies widely between species [50,51] and can be identified based on xylem water content and/or colour [52]. The TDP sensors are extensively used in various fields [36,43] and are preferred because of their simplicity, low energy requirement, accuracy and low cost [53-55]. TDP sensors have several advantages, and these include: i) the lack of a requirement to calibrate sensors for each species and ii) a more representative measurement of the sapflow flux density through integration of flux density along the length of the probe [56-58].

Developed at the University of Western Australia, Perth, Australia, the HRM sensors were validated against gravimetric measurements of transpiration, and have been used in published sapflow research since 1998 [41]. To the best of our knowledge this is the first time simultaneous performance of the two probes has been tested. This study also compares the performance and accuracy of HRM and TDP in estimating transpiration losses.

The ability of Australian native species to transpire when established on a landfill has not been evaluated before. Nevertheless, this information is critically important to determine the water balance of phytocapped landfill sites. Thus, TDP sensors, HRM sensors and dynagauges were installed in a range of native species that were grown on a phytocapped landfill. This Paper focuses on species differences in transpiration rates, seasonal variability and the difference between probes in determining sapflow.

\section{Materials and Methods}

Fifteen species with stem diameters of more than $50 \mathrm{~mm}$ (minimum requirement to install sapflow sensors) were selected for this study. Sapflow measurements were recorded for fifteen species grown on $1400 \mathrm{~mm}$ and $700 \mathrm{~mm}$ soil cover in Thin phytocap, due to practical constraints. From nine planted trees of each species in the experimental plot, a representative tree was selected depending on the stem diameter. Among the fifteen species selected at each batch of the study (5 to 30 days per batch), sapflow in fourteen species were recorded using TDP sensors (Figure 1) and sapflow in D latiflorus was recorded using a dynagauge. During installation, the bark was 
removed until the sapwood was visible. Two $1.5 \mathrm{~mm}$ holes were drilled $40 \mathrm{~cm}$ apart (Figure 1). Hydrogen peroxide was applied to the holes to restrict growth of the wood and to allow easy removal of the probes on completion of monitoring. The sensors were then installed carefully and covered with polystyrene shields (Figure 1) to avoid any damage to the needles during high winds. The sensors were then wrapped with aluminium foil (Figure 1) to minimise the effect of the external environment on sensor readings. Each sensor was connected to a smart logger via a monibus bar, and the sensors were powered by a $12 \mathrm{~V} \mathrm{DC}$ external battery which was continuously charged by an $80 \mathrm{~W}$ solar panel (Figure 2). Sap flow measurements were recorded for 24 hours on an hourly basis to check the functionality of the instrument. For bamboo, the dynagauges (collar sensor) was wrapped round the stem and wound tightly with the aid of velcro strips. A total of 49 observations were taken using various tree species, with each measurement ranging from 5 to 30 days.

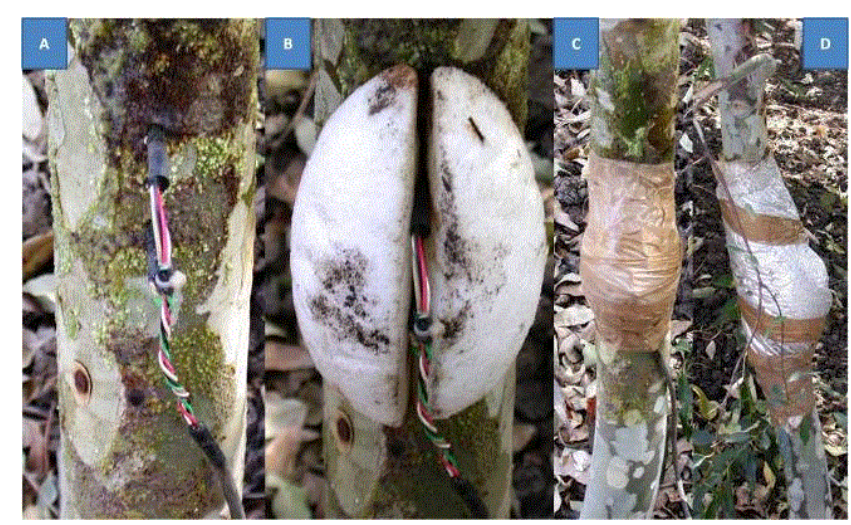

Figure 1: Installation of a TDP sensor A) TDP sensor installed, B) probes protected with polystyrene shield, and C) set up sealed and covered with aluminium foil.

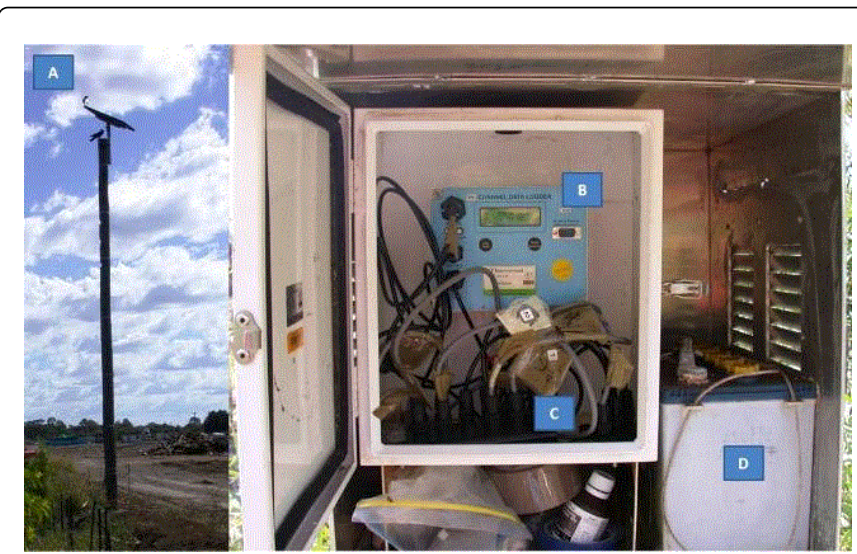

Figure 2: Power and sensor system used to measure sapflow. A) solar panel, B) smart logger, C) monibus bar and D) battery.

Sapflow was calculated from the measured sap velocity data. The raw data were imported to an Excel spreadsheet and the sap velocity readings from individual trees were multiplied by the sapwood area of each tree to obtain sapflow in $\mathrm{mm} \mathrm{d}^{-1}$. Parameters such as sapwood depth and wounding coefficient were used to calculate sapflow in individual trees [59]. The sapwood area was determined by destructive methods, when the selected trees were felled for biomass measurements in 2006. This was repeated in 2007. In the first instance, alternate trees from each Thick and Thin phytocap (nine trees) and from both replications were harvested. Of 9 trees harvested, 3 were studied for their above ground biomass, and the remaining 6 were harvested and measured for their $\mathrm{D}_{50}, \mathrm{DBH}$, sapwood depth and height. In 2007, 3 trees per species (representative of the entire stand) in Thick and Thin phytocaps and from both replications were selected and studied for their above ground biomass, and the rest were measured for their height, $\mathrm{D}_{50}, \mathrm{DBH}$ and sapwood depth. Sapwood depth measurements were taken at three locations (Figure 3 ) and the average of these was used to calculate the sapwood area (Figure 4) according to the method of Sharma [60], as shown.

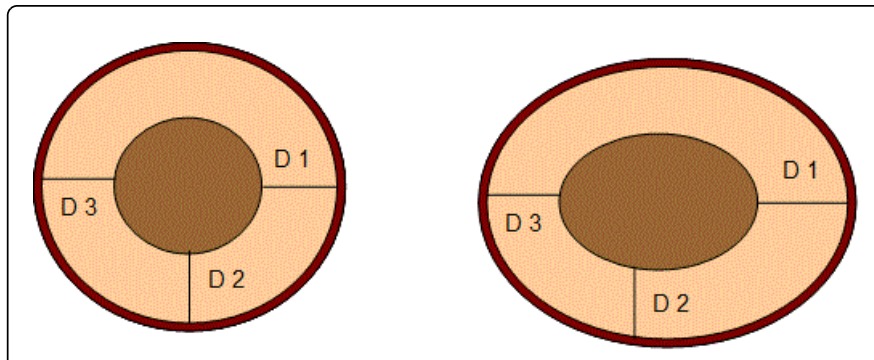

Figure 3: Sapwood depth measurement in cylindrical and noncylindrical stems.

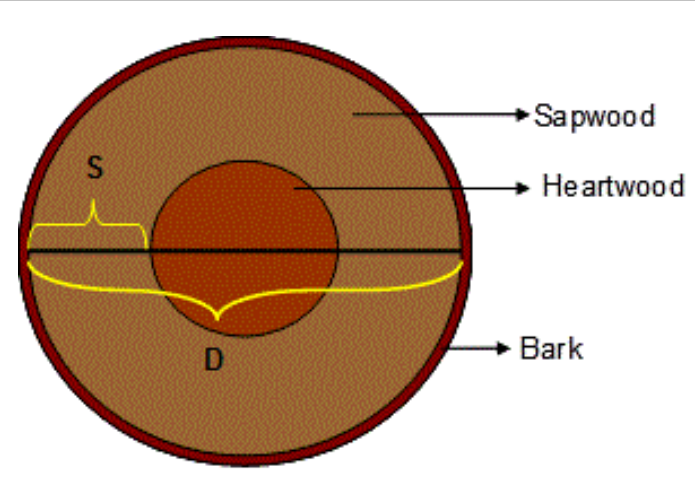

Figure 4: Cross section of a typical tree trunk ( $\mathrm{S}=$ sapwood depth, $\mathrm{D}=$ heartwood diameter).

Sapwood area=Cross sectional area of the stem (excluding bark)heartwood area

$$
\begin{aligned}
& \mathrm{A}=\pi(\mathrm{D} / 2) 2-\pi(\mathrm{D} / 2-\mathrm{S}) 2 \\
& =\pi\{\mathrm{D} 2 / 4-(\mathrm{D} 2 / 4+\mathrm{S}) 2)\} \\
& \mathrm{A}=\pi \mathrm{S}(\mathrm{D}-\mathrm{S}) .
\end{aligned}
$$

Where D is under bark diameter of the tree and S is the sap wood depth

\section{Comparison between HRM vs TDP sensors}

Six E. grandis trees that had similar stem diameter and height were selected for the study. From the six selected trees, three randomly selected trees were installed with TDP sensors and the other three were installed with HRM sensors. 
Citation: Venkatraman K, Ashwath N (2016) Transpiration in 15 Tree Species Grown on a Phytocapped Landfill Site. Hydrol Current Res 7: 236.

HRM sensors were installed using similar procedures as for the TDP sensor (Figure 5). The installed sensors could cause mechanical damage or they may interrupt flow by occlusion or blocking of the plant's vascular tissues [59], resulting in growth of non-conducting tissues directly surrounding the probe. This type of growth, if any, was corrected to achieve accurate results. Wound correction coefficients applicable to a range of wound sizes were generated using numerical models to obtain accurate values (Alec Downey, personal communication). These corrections can be implemented either automatically or they can be introduced manually after collecting the data of raw heat pulse velocities (Alec Downey, personal communication).

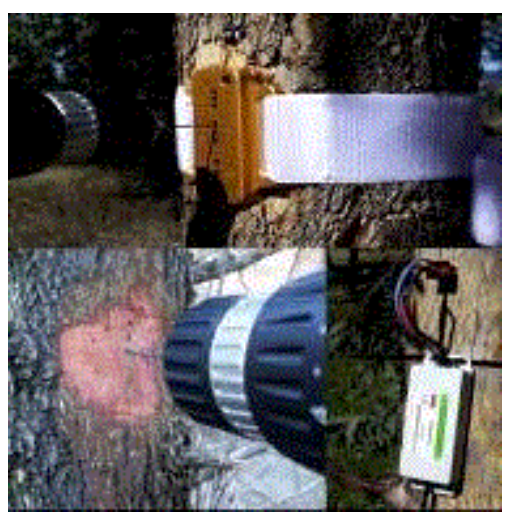

Figure 5: Installation of HRM sensor.

\section{Testing sensor accuracy}

Three G. lobocarpum were carefully excavated from the phytocap and transferred into large planter bags which were then filled with soil collected from the same field and placed on wooden pallets (Figure 6). The planter bags were then mulched to reduce soil evaporation. TDP sensors were installed in each tree and then connected to the smart logger. After 4 weeks of establishment, the initial weight of each pot was taken using a pallet scale. A known amount of water (up to $30 \mathrm{~L}$ ) was added to the pots and they were re-weighed. The pots were then weighed after 24 hours. The difference in initial and final weight was used to estimate the water taken up by each tree in 24 hours. Simultaneously, sapflow readings as determined by TDP sensors were calculated, assuming that the soil evaporation from the mulched pot was minimal and uniform amongst the three tested plants.

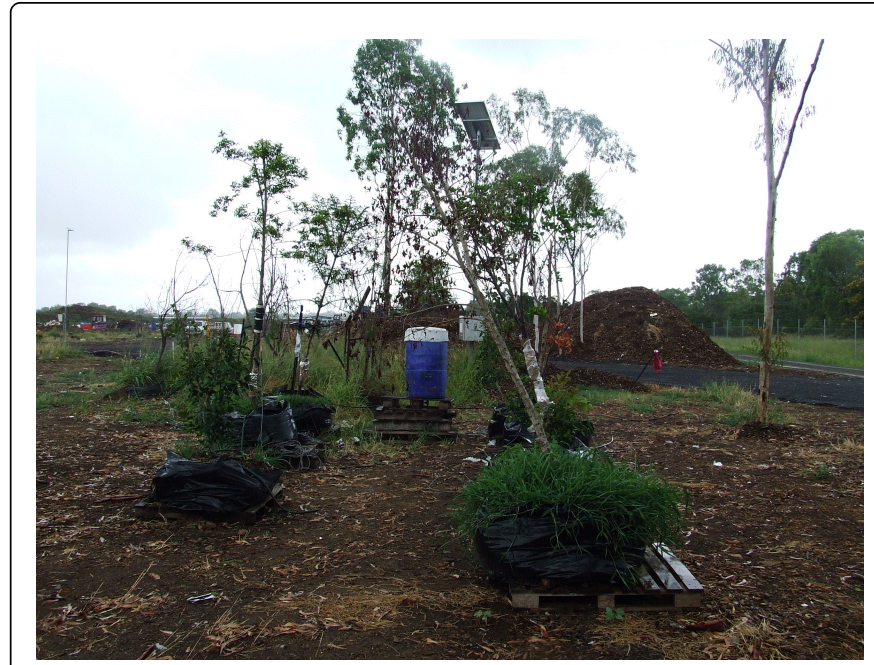

Figure 6: Transplanted Cupaniopsis anacardioides saplings placed on a pallet scale.

\section{Soil moisture determination}

Soil moisture in this study was monitored using micro-gopher, which has a logger and $1 \mathrm{~m}$ long $(<25 \mathrm{~cm}$ diameter) calibrated $(10 \mathrm{~cm}$ intervals) rod with a sensor at the tip of the rod. 84 gopher access tubes made of PVC were installed throughout the experimental plot (21 gopher access tubes per experimental plot). Each gopher tube had a diameter of $25 \mathrm{~mm}$ was 1.2 metre long. The bottom end of the access tubes was sealed and the top end was capped while not in use (Figure 7). During measurement the micro gopher rod was inserted into tubes upto $1 \mathrm{~m}$ each time, with $10 \mathrm{~cm}$ interval. Soil moisture levels at $10 \mathrm{~cm}$ increments were taken from each access tube. Monitoring of soil moisture was continued at regular intervals (every month). As discussed, changes in soil moisture were recorded at 10 different depths for each of the 84 tubes in the plot. The results in soil moisture were related to plant growth and their capacity to transpire.

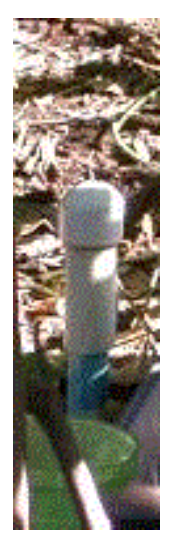

Figure 7: Micro Gopher access tube. 
Page 5 of 13

\section{Statistical analysis}

The sapflow data were subjected to ANOVA using Genstat ver. 8.0, after testing for outliers and homogeneity of error variances. Least significance differences were used when ANOVA tests for species, capping, season or their interactions were found significant. The effects of various tree parameters on transpiration rates were assessed using regression equations (GraphPad Prism v 4.03 and Genstat ver. 13) and the linear equation was chosen as it produced the highest $r^{2}$ values.

\section{Results and Discussion}

\section{Transpiration rates}

Fifteen of the 21 species were tested for transpiration rates (over 2 years) as they were the only species that grew to $50 \mathrm{~mm}$ diameter (minimum requirement for installing TDP or HRM sensors). Transpiration rates ranged between $0.9 \mathrm{~mm} \mathrm{~d}-1$ to $2.1 \mathrm{~mm} \mathrm{~d}-1$ (average of 49 observations), with an overall average (for all species and all seasons over 2 years) of $1.4 \mathrm{~mm} \mathrm{~d}-1$ (Figure 8). Acacia mangium, $H$. tiliaceus, C. cunninghamiana and E. raveretiana had high transpiration rates (2 $\mathrm{mm} \mathrm{d}-1)$ (Figure 8$)$. Transpiration rates monitored over 2 years were as low as $0.1 \mathrm{~mm} \mathrm{~d}-1$ and as high as 6.25 $\mathrm{mm} \mathrm{d}-1$ (Table 1). This large range in transpiration rates in individual species may be due to variations in growth rates amongst seasons, rainfall, temperature, wind velocity, vapour pressure deficit and solar radiation as explained by Eamus et al. [3]. These variations demonstrate the ability of the species to transpire copiously during high rainfall period and very little during dry seasons. Such behaviour in plants is highly sought after for species to be grown of phytocaps, as these systems lack access to sub soil moisture unlike those present on natural landscapes.

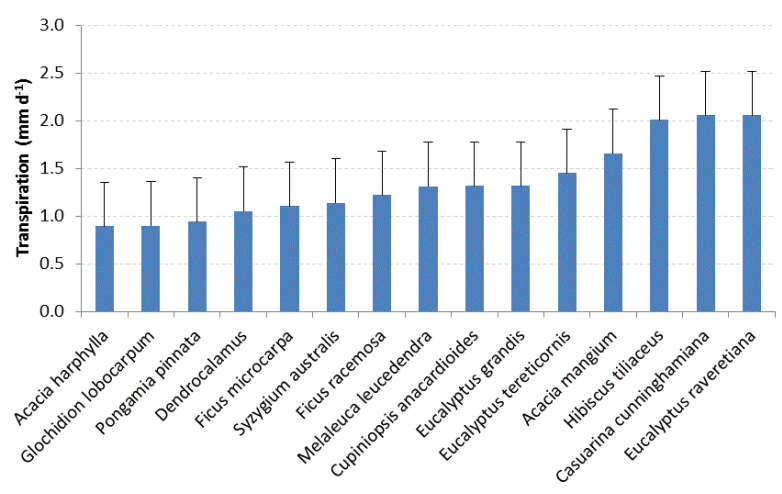

Figure 8: Transpiration rates of 15 species grown on a phytocap for 2 years (49 observations) (Bars represent l.s.d. 0.46).

\begin{tabular}{|l|l|}
\hline Species & Transpiration $(\mathbf{m m} /$ day) \\
\hline Acacia harpophylla & $0.35-2.69$ \\
\hline Acacia mangium & $0.45-4.0$ \\
\hline Casuarina cunninghamiana & $0.36-3.93$ \\
\hline Cupaniopsis anacardioides & $0.6-26$ \\
\hline Dendrocalamus latiflorus & $0.36-4.5$ \\
\hline
\end{tabular}

\begin{tabular}{|l|l|}
\hline Eucalyptus grandis & $0.22-4$ \\
\hline Eucalyptus raveretiana & $0.35-3.7$ \\
\hline Eucalyptus tereticornis & $0.28-4.0$ \\
\hline Ficus microcarpa & $0.26-4.0$ \\
\hline Ficus racemosa & $0.2-2.7$ \\
\hline Glochidion lobocarpum & $0.1-1.53$ \\
\hline Hibiscus tiliaceus & $0.36-6.25$ \\
\hline Melaleuca leucadendra & $0.2-2.67$ \\
\hline Pongamia pinnata & $0.1-2.64$ \\
\hline Syzygium australis & $0.3-2.56$ \\
\hline
\end{tabular}

Table 1: Range in transpiration rates of 15 species grown on phytocaps over a 2 year period $(n=49)$.

Trees grown on phytocaps varied significantly $(\mathrm{P}<0.01)$ in their transpiration rates (Figure 8 ) and this can be attributed to differing performances of these species in different seasons associated with variations in soil moisture regimes [17], leaf area [20], leaf biomass $[25,26]$ solar radiation $[4,61]$, and root development. Although all species experienced the same climatic conditions and seasonal change, they differed largely in their LAI, leaf biomass and root development. Furthermore, factors such as soil water availability and solar radiation reaching the tree canopy would have varied seasonally and at different times during the day. Variation in transpiration rates between species and among trees of the same species was due to height increments within stand, as the slow growing species were shaded by the faster growing/dominating species, resulting in them acquiring minimum sunlight and energy to transpire.

In many cases, canopy rainfall interception plays a vital role in controlling soil moisture level [17]. However, in this study, no significant effect of canopy interception on soil moisture levels both in Thick and Thin phytocaps was noticed. Variations in the quantity of leaf litter produced by the 15 species may also have an influence on the soil moisture levels over small distances. However, the differences in soil moisture levels were prominent due to rainfall interception by the tree leaves and leaf litter that may have reduced the quantity of water reaching the soil. Similarly, variation in the height of species due to competition for sunlight and other resources greatly influenced transpiration rates.

\section{Diurnal variation in transpiration rates}

Diurnal variation in water uptake depends on the incident solar radiation on the canopy [3]. The diurnal pattern in two 3-year-old $E$. grandis trees grown on the phytocaps with a stem diameter of $107 \mathrm{~mm}$ and $105 \mathrm{~mm}$ respectively is shown in Figure 9. All species tested showed similar transpiration pattern with close to zero or zero at night increasing to a maximum at noon. As explained by Eamus [3], solar radiation increases to the highest level at midday (Figure 10) and hence the transpiration rates are expected to follow the same pattern. However, this is not the case in many species due to a time lag in the water movement due to resistance to water flow between the soil and the leaves [3]. There was a time lag in water uptake by E. grandis grown in the phytocapping system (Figure 11). 
Citation: Venkatraman K, Ashwath N (2016) Transpiration in 15 Tree Species Grown on a Phytocapped Landfill Site. Hydrol Current Res 7: 236.

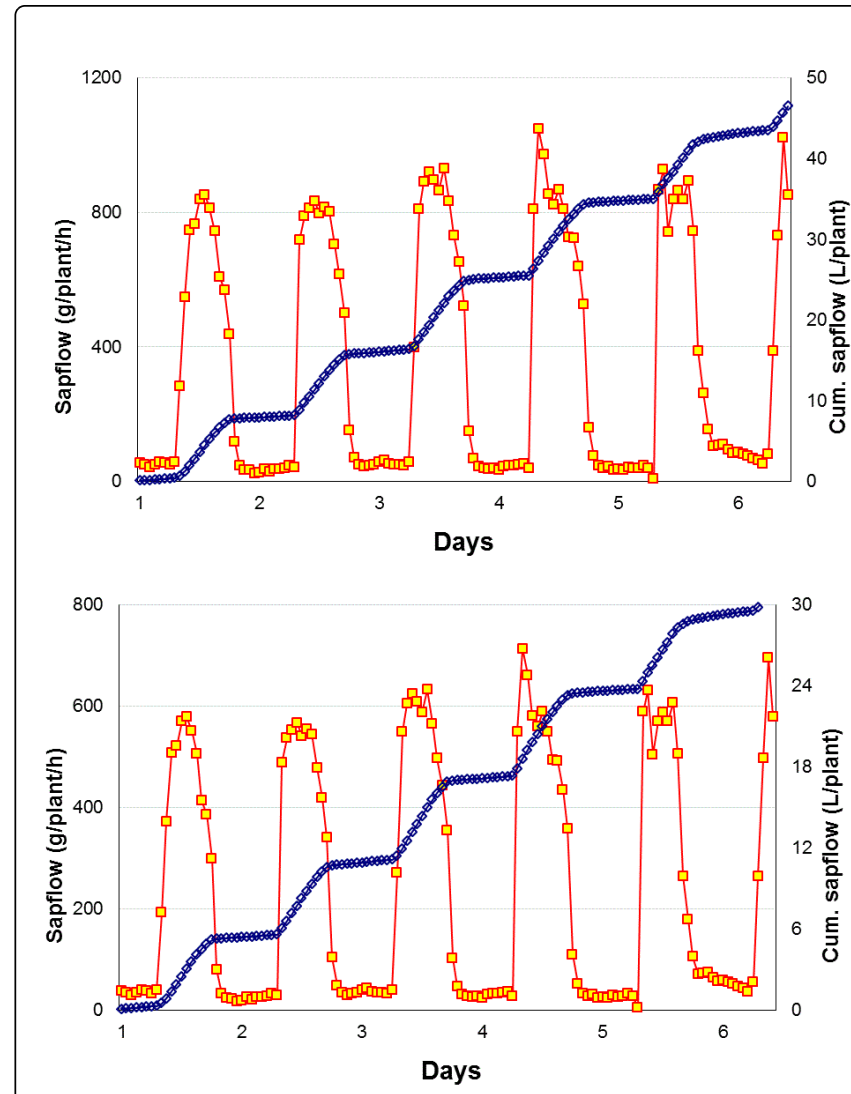

Figure 9: Diurnal variations in transpiration rates of two 3-year-old Eucalyptus grandis trees.

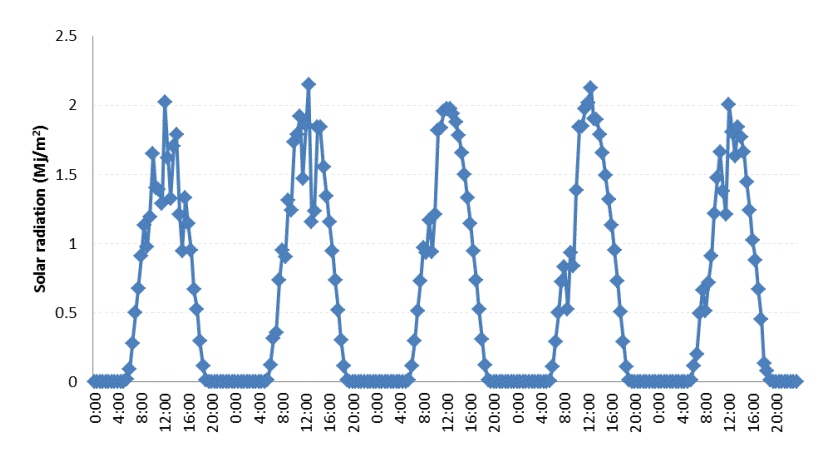

Time

Figure 10: Solar radiation observed in January 2006 over five days $(1 / 01 / 2006-5 / 01 / 2006)$.

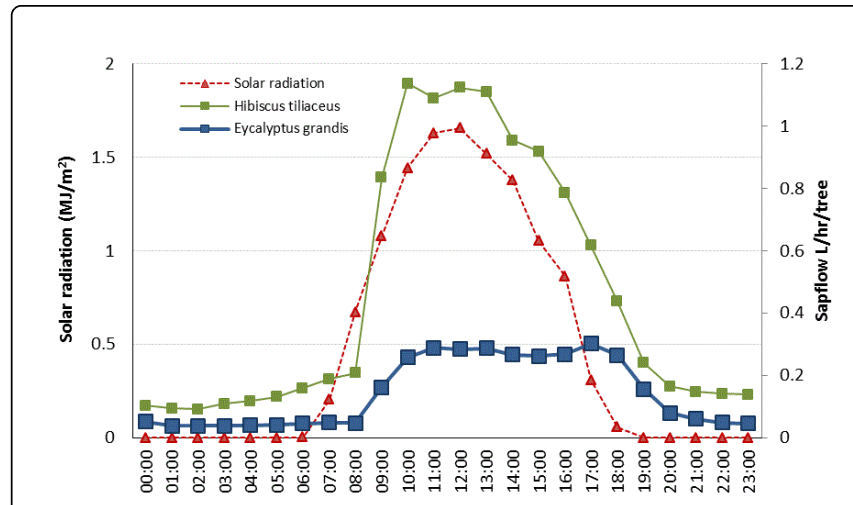

Figure 11: Solar radiation and associated transpiration pattern in $H$. tiliaceus and E. grandis observed in April 2007.

In this study, the influence of seasonal changes on transpiration rates has not been clearly understood because of the lack of continuous monitoring of the same tree over several seasons. However, data of some species have showed their ability to respond to wet and dry cycles. For example data of $\mathrm{H}$. tiliaceus shows its ability to adapt to site moisture conditions by transpiring as high as $15 \mathrm{~L} \mathrm{~d}-1$ after a rainfall event and as low as $0.4 \mathrm{~L} \mathrm{~d}-1$ during dry periods (Figures 12 and 13). Similar trends were observed by Eamus et al. [3] in E. grandis and E. globulus in the Victorian climate. E. grandis was able of take up 0.89 $\mathrm{mm} \mathrm{d}-1$ of water. E. globulus, on the other hand, transpired $2.2 \mathrm{~mm}$ d-1 during late spring (rainy season) and only $0.33 \mathrm{~mm} \mathrm{~d}-1$ during summer (drought). This behaviour of the species is extremely important in phytocapping, as seasonal availability of water in Australia is highly variable. This is illustrated in H. tiliaceus (Figures 12 and 13). A medium size tree such as $\mathrm{H}$. tiliaceus could survive in both wet and dry cycles, and this demonstrates the capacity of the species to both persist on the site during drought and rapidly remove water during the rainy season.

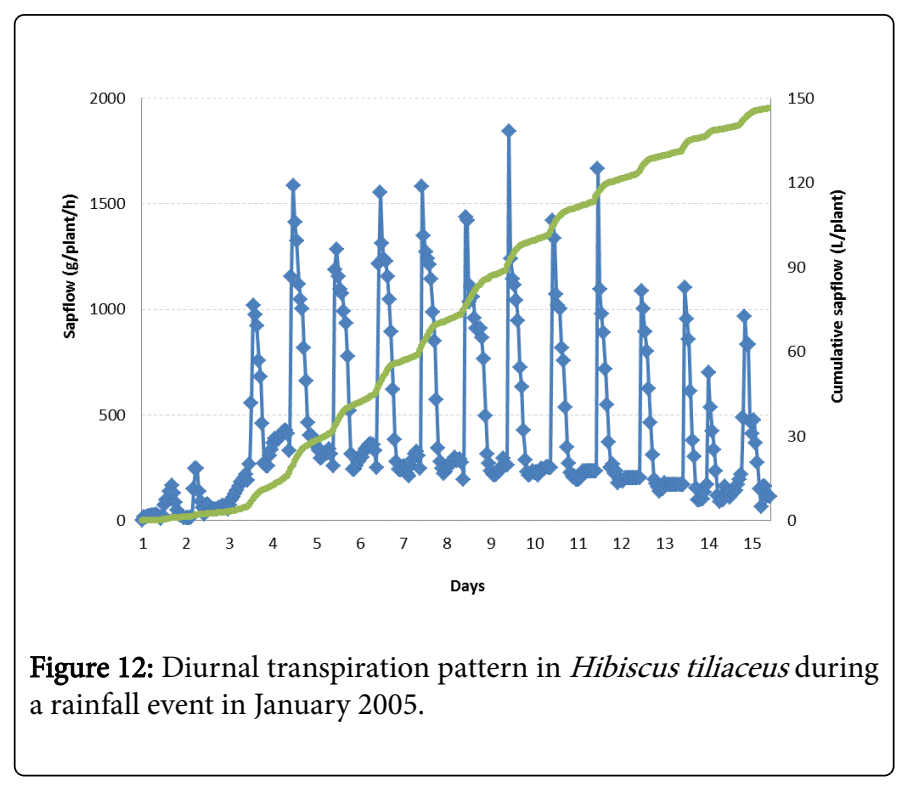




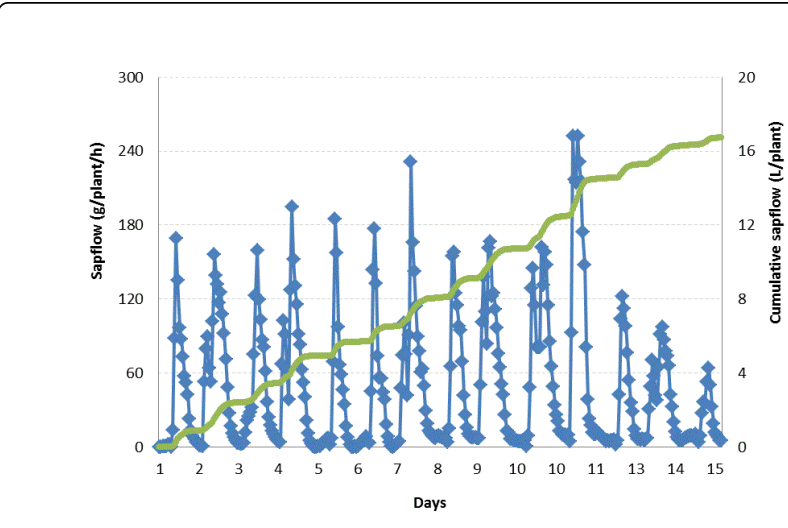

Figure 13: Diurnal transpiration pattern in Hibiscus tiliaceus during a dry period in May 2005.

Transpiration rates in bamboo ranged between $0.36 \mathrm{~mm}$ d- 1 to 4.5 mm d-1 (Table 1). Results from twelve observations spanning over 18 months (July 2005 to Dec 2006) suggest that the bamboo transpired on an average $1.2 \mathrm{~mm} \mathrm{~d}-1$ (Figure 11). These patterns further illustrate that transpiration increases during wet seasons, maintains averages during normal seasons and declines severely during dry seasons. Similar results have been reported by Li et al. [62] in corn and by Katul et al. [63] in oak.

\section{Species response to rainfall}

How quickly a tree responds to each rainfall event is important in judging the suitability of a species to be grown on phytocaps. Thus a short experiment was conducted in June 2006 on a bright sunny day. Six species that were installed with sapflow sensors were irrigated (100 L) between $7.00 \mathrm{am}$ and $7.30 \mathrm{am}$ and their response to this irrigation was monitored. Most species were able to take up water within the first two hours of irrigation (Figure 14). A few species such as A. harpophylla, A. mangium and G. lobocarpum responded to the changed conditions and were able to take up water within one hour of irrigation (Figure 14). M. leucadendra showed the unique trend of a very high uptake followed by a steep decline (Figure 14), which could be attributed to environmental factors such as insects, wind and/or fluid in the wound affecting the sensor. The other species showed a sharp increase in water uptake followed by a gradual decrease over 4 to 5 hours. This immediate response to rainfall events is very important in maintaining the hydrological balance of the phytocaps. Similar research is needed over a longer term to test the inherent ability of the species to respond to rainfall and drought. These results clearly suggest that the trees grown on this phytocapping system have the ability to adapt and respond well to frequent wet and dry cycles thereby taking up water quickly and avoiding excess water flowing through the soil layers into the buried waste.

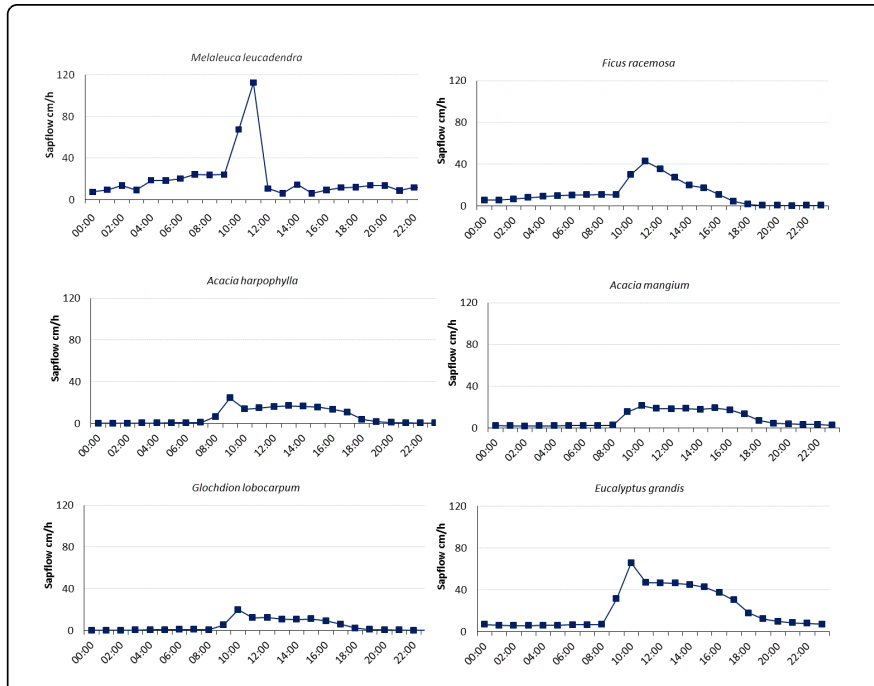

Figure 14: Response to irrigation by 3-year-old trees grown on the Thin phytocap.

Another experiment conducted in early 2007, during the wet season when a rainfall event $(37.5 \mathrm{~mm})$ occurred after a dry period, is shown in Figure 15. Sapflow patterns were monitored for 3 consecutive days following the rainfall event. The results showed an increase in transpiration rates in $\mathrm{H}$. tiliaceus, P. pinnata, E. raveretiana and Ficus macrocarpa after the rainfall event on the fourth day (Figure 15). Similar trends were observed in a number of other species. This indicates that the trees grown in the phytocapping system rapidly enhanced their transpiration rates within hours of a rainfall event; thereby removing stored water from the soil layer. The extent to which these remove water will show superiority of one species over the other. This concept was explained by Ansley et al. [30] in honey mesquite in Vernon, Texas. This cyclic nature of trees to increase, maintain and lower transpiration rates in response to rainfall and moisture limitation is critically important, not only for judging the effectiveness of the phytocaps, but also for the long-term survival of the species on the phytocaps.

\section{Factors influencing transpiration}

Transpiration rates are determined by the size of the plant and its potential to transpire water rapidly. Hence the observed values of transpiration were correlated with growth parameters. Transpiration rates showed a significant correlation with tree height, DBH, D50, LAI and shoot biomass (Table 2). Previous studies have demonstrated positive relationships between transpiration rates and tree height or stem diameter [64]. Biomass accumulation also directly correlates with water uptake $[65,66]$. Taller trees have a greater canopy exposure to solar radiation, allowing them to increase in stem diameter [67].

In a mixed stand, competition exists between species, and among trees of the same species for resources such as light, water and food. Fast growing trees such as A. mangium, H. tiliaceus, casuarinas, bamboo and eucalypts grew more than $6 \mathrm{~m}$ tall in 3 years and most species grew over $2 \mathrm{~m}$. Callistemon viminalis and M. linariifolia were the only two species that showed very slow growth rate. Similar findings were reported by Wright and Westo [12]. This large variation 
in growth rate is partially genetic and partially due to competition for light between tall and short species [68].

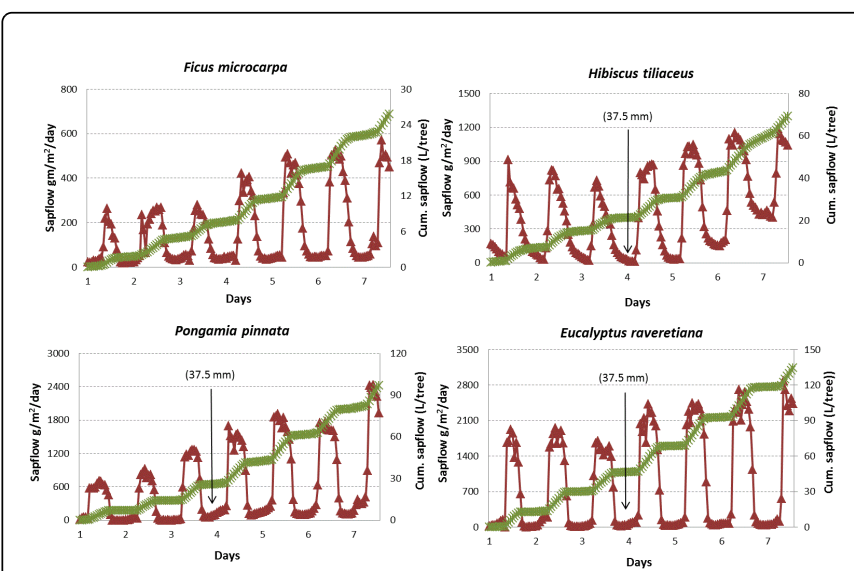

Figure 15: Water uptake by four species after a $37.5 \mathrm{~mm}$ rainfall event.

\begin{tabular}{|l|l|}
\hline Parameter & $\mathbf{r}^{2}$ value \\
\hline Height & $0.54^{* *}$ \\
\hline DBH & $0.50^{\star *}$ \\
\hline $\mathrm{D}_{50}$ & $0.55^{\star *}$ \\
\hline Shoot biomass & $0.38^{\star}$ \\
\hline Root Biomass & $0.076 \mathrm{~ns}$ \\
\hline Root depth & $0.07 \mathrm{~ns}$ \\
\hline LAl & $0.40^{\star}$ \\
\hline Canopy area & $0.18 \mathrm{~ns}$ \\
\hline Leaf Area & $0.051 \mathrm{~ns}$ \\
\hline
\end{tabular}

Table 2: Correlation between transpiration rates and various tree parameters for the 15 species grown on Thick and Thin phytocaps.

In a mixed stand, competition exists between species, and among trees of the same species for resources such as light, water and food. Fast growing trees such as A. mangium, H. tiliaceus, casuarinas, bamboo and eucalypts grew more than $6 \mathrm{~m}$ tall in 3 years and most species grew over $2 \mathrm{~m}$. Callistemon viminalis and M. linariifolia were the only two species that showed very slow growth rate. Similar findings were reported by Wright and Westo [12]. This large variation in growth rate is partially genetic and partially due to competition for light between tall and short species [68].

Transpiration in the 15 species tested varied significantly $(\mathrm{P}<0.001)$ between seasons (Figure 16) primarily due to moisture availability, solar radiation, leaf area and season. Transpiration was higher during the low rainfall period (April to October) than during the high rainfall period (November to March). This could be attributed to high evaporation during low rainfall periods and fluctuation in other environmental factors such as VPD and solar radiation during rainfall events.

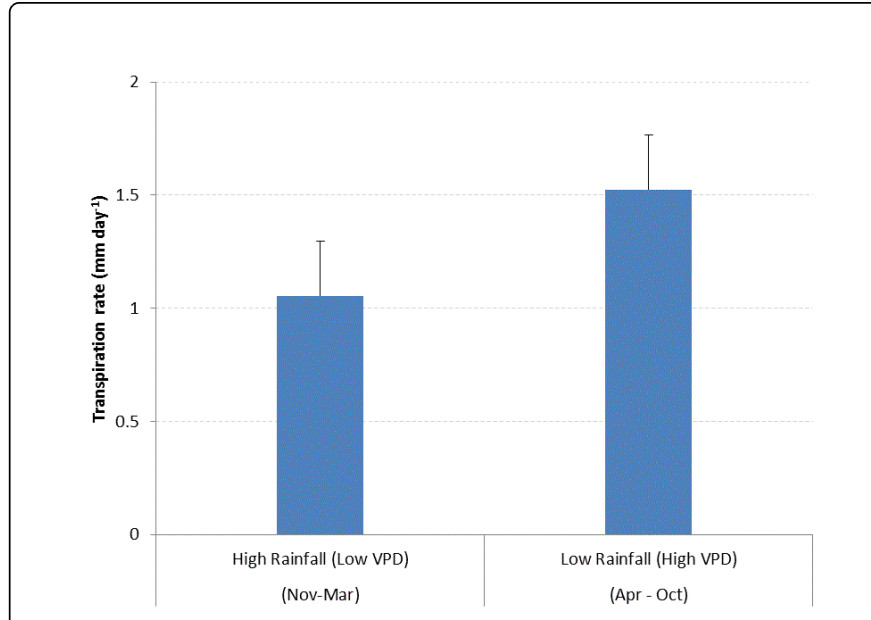

Figure 16: Effect of season on transpiration rates (Bar represents l.s.d. 0.242).

Differences in transpiration between species and those between individuals of the same species are expected to reduce with tree height and age as explained by Ryan [24]. Such differences may be caused by differences in hydraulic resistance of the soil-to-leaf pathway, which may be due to the variations in the path length (stem height) and the sapwood permeability.

The amount of solar radiation increases from zero at night to the maximum during the day. Since solar radiation increases in the morning and decreases by afternoon, it is expected that the transpiration in trees would follow a similar pattern. However, resistance in water movement between the soil and the leaf does not allow transpiration to take place instantaneously and a time lag between increasing transpiration rates and increasing water uptake by the roots was observed (Figure 17).

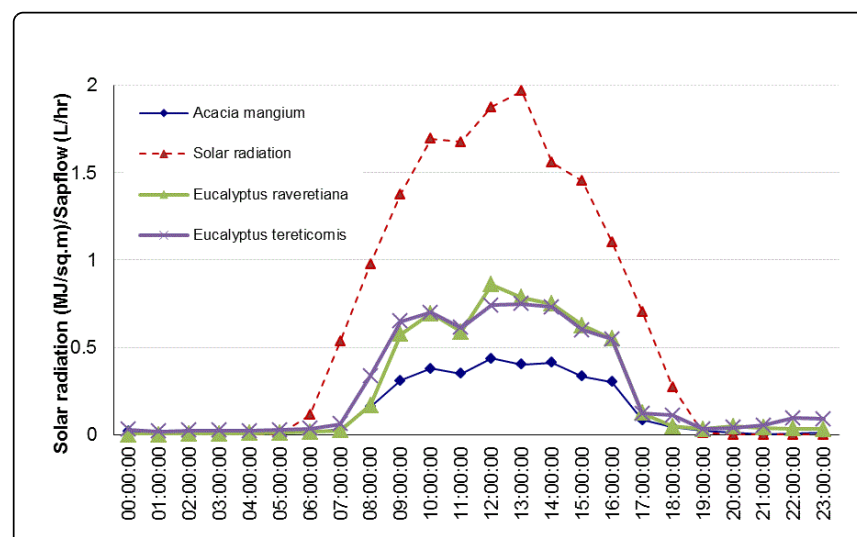

Figure 17: Effect of solar radiation on sapflow in 3 year-old Eucalyptus raveretiana, Eucalyptus grandis and Acacia mangium (March 2007).

Sapwood is the primary component of the stem that conducts water [51]. The 3-year-old species differed in their sapwood depth (Figure 
18) which showed a strong correlation $(\mathrm{P}<0.001)$ with transpiration rates (Figures 18 and 19) as the quantity of water absorbed by the sapwood is influenced by its density and size [39]. However, transpiration rates are expected to decrease with the age of the tree. As the trees age, the sapwood depth increases, thus decreasing density of the sapwood.

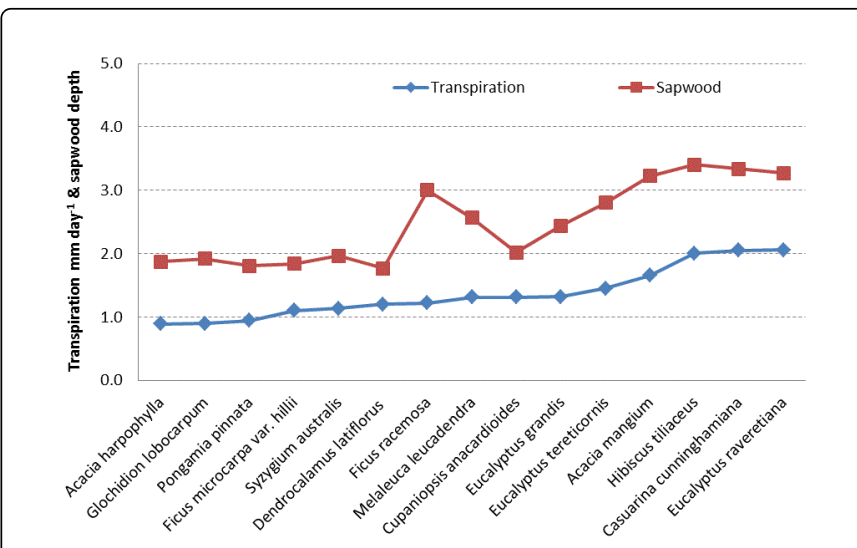

Figure 18: Variations in sapwood depth $(\mathrm{cm})$ and transpiration in 15 species grown on a Thick and Thin phytocap for 3.5 years.

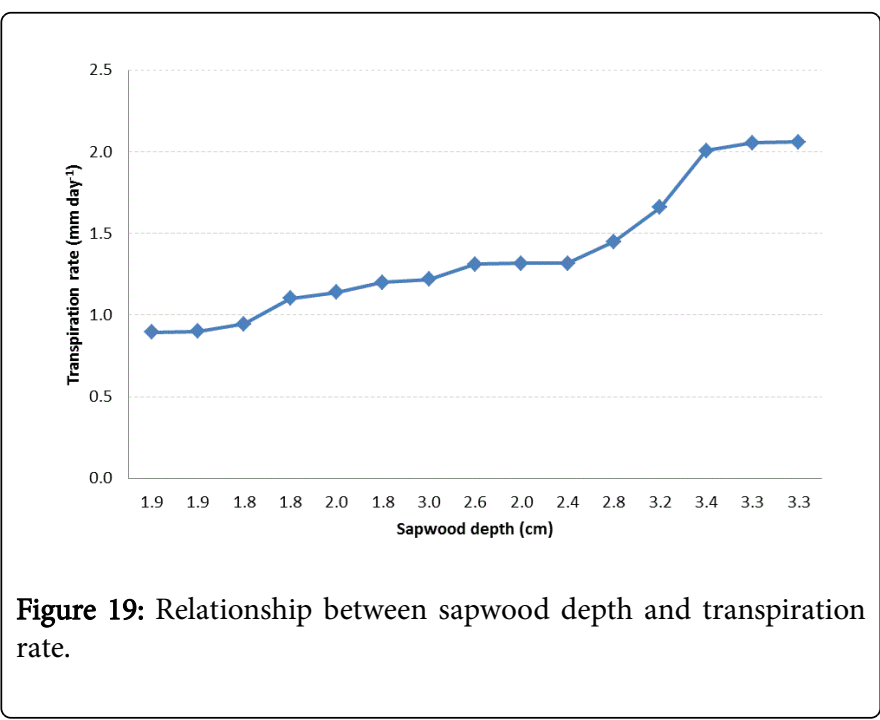

In the current study, trees grown in phytocaps were regularly irrigated (Figure 20) during establishment (first 15 months from 2003 to 2004) and then when they showed severe wilting symptoms. The frequency of water supply was reduced after 15 months of planting (in 2005). Thus the plants were unlikely to be exposed to regular dry periods when they were monitored for transpiration rates. Higher transpiration rates during low rainfall periods may be due to higher VPD.

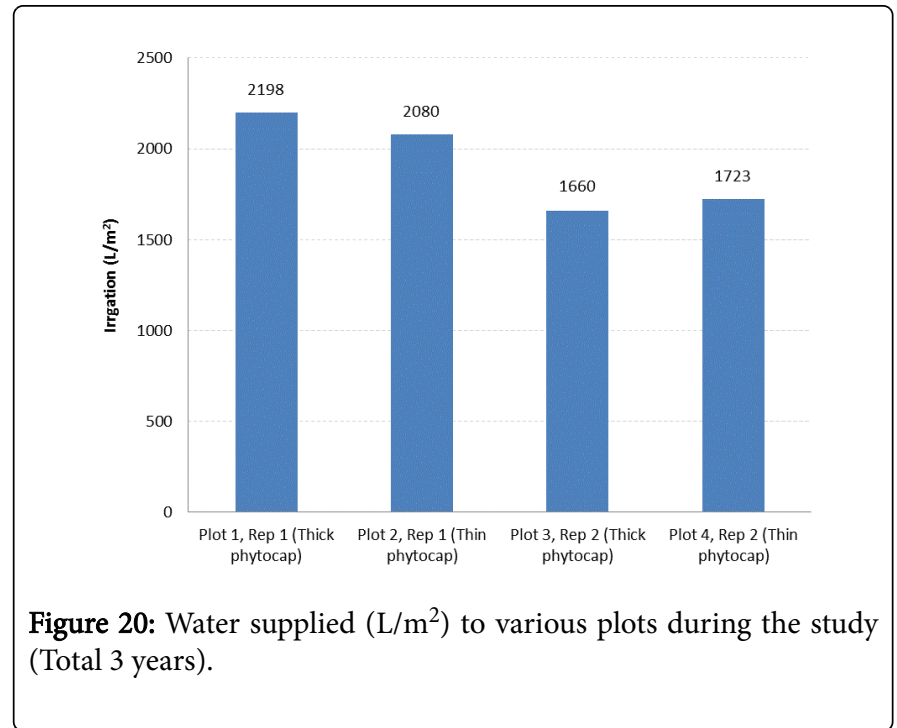

\section{Effect of transpiration on soil moisture profiles}

Average soil moisture content (100 cm depth) under each species varied significantly $(\mathrm{P}<0.001)$ between species and between Thick and Thin phytocaps (Figure 21). This was primarily due to variation in rainfall pattern as clearly reflected in the soil moisture content and quick response of trees to take up water during rain events. Similar observations were made by Ansley et al. [29,30].

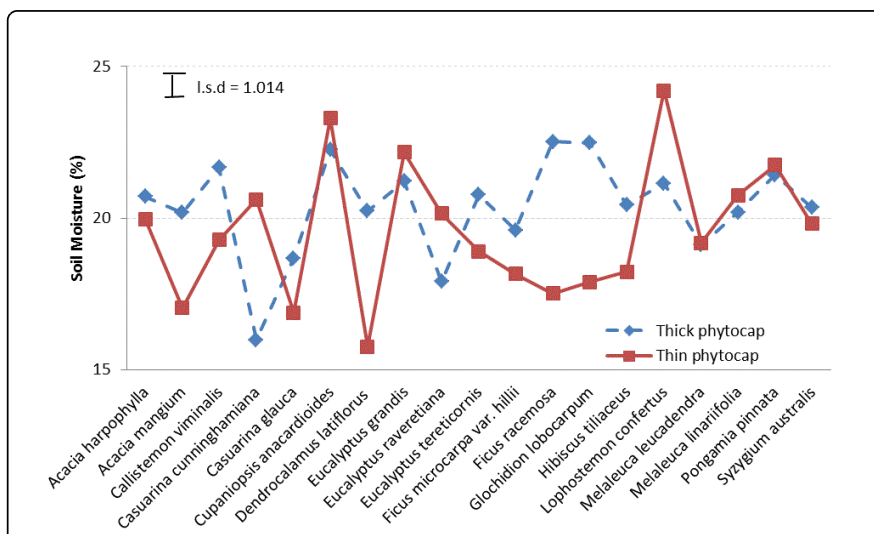

Figure 21: Variation in soil moisture content in the root zone of each species in Thin and Thick phytocaps (Average of 51 observations).

Soil moisture content varied significantly $(\mathrm{P}<0.001)$ between Thick and Thin phytocaps (Figure 22) and was due to difference in plant growth rates and soil depth as well as the variation in the chemical and physical properties of the soils used in the two phytocaps.

Soil moisture levels also varied significantly $(\mathrm{P}<0.001)$ with rainfall (Figure 23), and this is because the potential evapotranspiration exceeds rainfall in Rockhampton. In this situation, soil dries to the point where hydraulic conductivity becomes very low and any rainfall that occurs will wet the soil uniformly and is lost through transpiration and evaporation before any significant lateral redistribution takes place [69]. As evapotranspiration decreases and rainfall increases, the soil 
Citation: Venkatraman K, Ashwath N (2016) Transpiration in 15 Tree Species Grown on a Phytocapped Landfill Site. Hydrol Current Res 7: 236.

surface gets saturated and thereby generating more runoff. In the wet to dry transitional period, a rapid increase in potential evapotranspiration (and possibly a decrease in rainfall) causes drying of the soil [69].

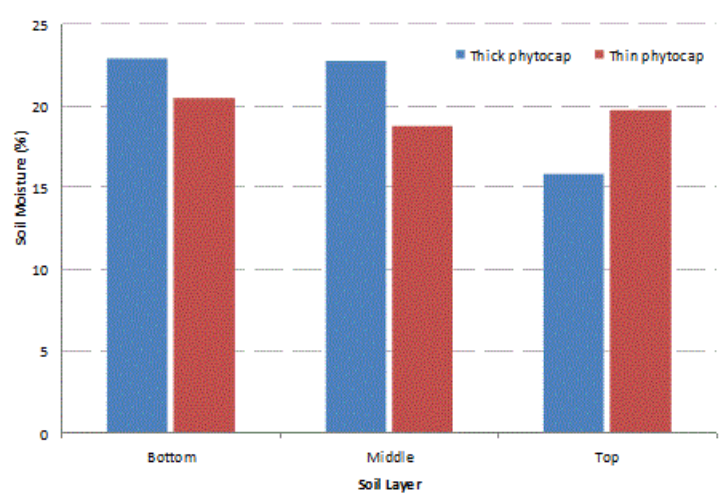

Figure 22: Soil moisture content at the top $(0-300 \mathrm{~mm})$, middle (301 $\mathrm{mm}-600 \mathrm{~mm})$ and bottom $(601 \mathrm{~mm}-900 \mathrm{~mm})$ of the Thick and Thin phytocaps.

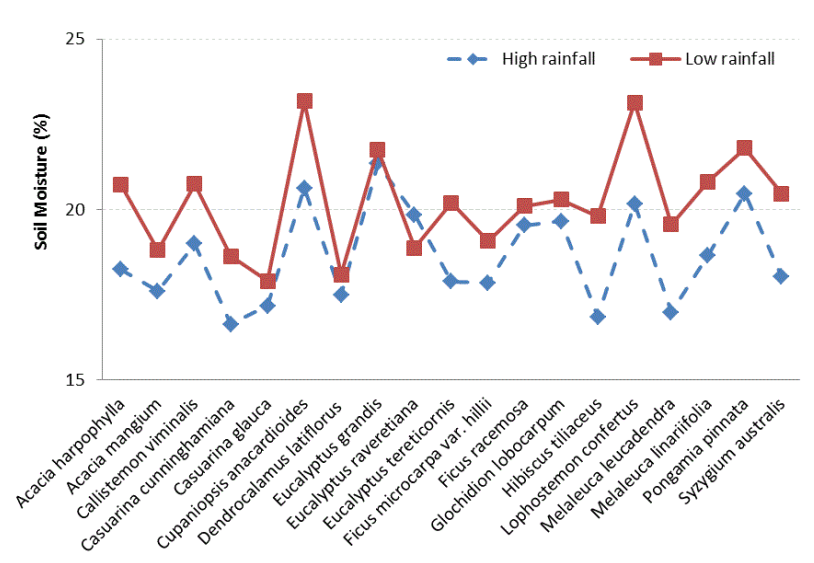

Figure 23: Soil moisture content in $100 \mathrm{~cm}$ depth soil during low and high rainfall events (l.s.d 1.81).

Soil moisture data taken after a $16 \mathrm{~mm}$ rainfall event showed significant difference between phytocaps and the non-vegetated site. The difference in soil moisture content was $40 \%$ (Figure 24), clearly showing the role that trees play in reducing water infiltration into the buried waste. Another test conducted to examine the effectiveness of phytocaps to reduce soil moisture levels after a rain event suggests that the species grown on phytocaps can transpire the water received within days; thus contributing to reduction in percolation (Figure 25). Figure 25 also shows species that responded quickly to increase in soil moisture levels.

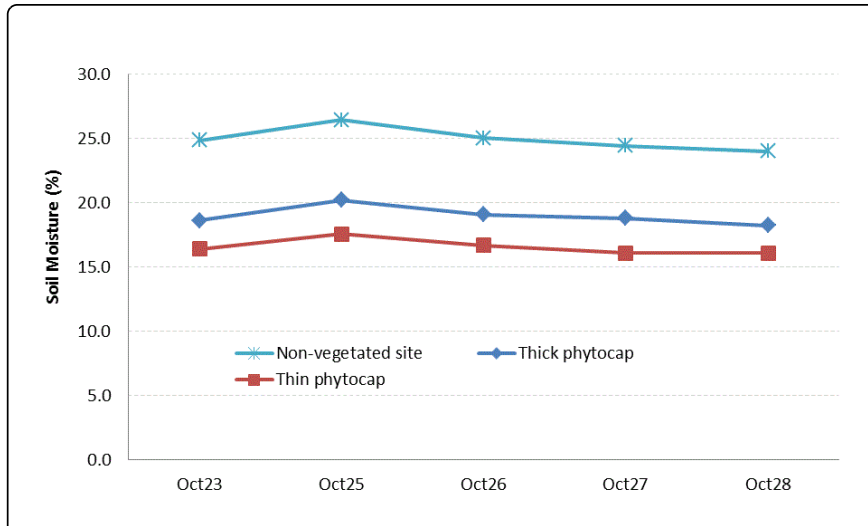

Figure 24: Soil moisture content of phytocaps and a non-vegetated site before and after a $16 \mathrm{~mm}$ rainfall in October 2006 (Average of 38 access tubes).

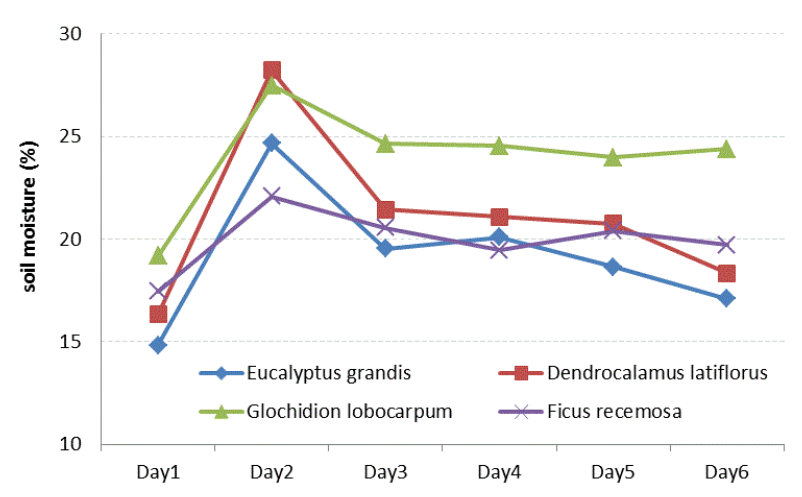

Figure 25: Water uptake in four tree species after supplying $100 \mathrm{~L}$ of water to each species.

\section{Comparison between TDP and HRM sensors}

Therman Dissipation Probe and Heat Ratio Method can be effectively used to measure sap flow in tree stems. Although the heat pulse technique has previously been shown to provide accurate estimates of sap flow in Eucalyptus species [70,71], errors associated with the estimation of sapwood area (as high as 38\%; Hatton et al. [35]) could make the results highly variable. Experiments conducted during this study suggested that the three-year-old E. grandis with slightly variable stem diameter and canopy spread was able to take up 0.80 to $2.5 \mathrm{~mm}$ d- 1 tree- 1 (Table 3 ).

\begin{tabular}{|l|l|l|l|l|l|}
\hline Tree no. & $\begin{array}{l}\text { Tree Age } \\
(\text { (years) }\end{array}$ & $\begin{array}{l}\text { Canopy } \\
\mathbf{s p r e a d} \\
\left(\mathbf{m}^{2}\right)\end{array}$ & $\begin{array}{l}\text { Sensor } \\
\text { type }\end{array}$ & $\begin{array}{l}\text { Stem } \\
\text { diameter } \\
(\mathbf{m m})\end{array}$ & $\begin{array}{l}\text { Sapflow } \\
(\mathbf{m m} \text { d-1 })\end{array}$ \\
\hline 1 & 3 & 4.15 & TDP & 105 & 1.9 \\
\hline 2 & 3 & 4.09 & TDP & 107 & 2.4 \\
\hline 3 & 3 & 4.16 & TDP & 124 & 2.3 \\
\hline 4 & 3 & 5.02 & HRM & 76 & 0.8 \\
\hline
\end{tabular}


Page 11 of 13

\begin{tabular}{|l|l|l|l|l|l|}
\hline 5 & 3 & 4.6 & HRM & 116 & 2.5 \\
\hline 6 & 3 & 4.12 & HRM & 124 & 1.8 \\
\hline
\end{tabular}

\section{Testing sensor accuracy}

Results from an experiment conducted to test accuracy of sensors suggest that although there may have been various external factors such as soil evaporation and wind speed affecting weight of pots, the

Table 3: Sapflow measurements in Eucalyptus grandis obtained by TDP and HRM sensors.

Table 3 shows the sapflow values obtained for six E. grandis trees with varied stem diameter and Canopy spread. Sapflow measurement calculations in this instance were based on the Canopy spread of individual trees.

Tree to tree variability of sap flow was significant $(\mathrm{P}<0.001)$, with trees and day interactions (Figure 26). This is expected as sap flow varies with season, climatic conditions, size of the plant and root development [27]. Sapwood depth varied widely among species and within the species which may also have a significant influence on sap flow.

Significant $(\mathrm{P}<0.001)$ variations were found between TDP and HRM sensors (Figure 26). Both TDP and HRM sensors are moderately destructive techniques due to the insertions of the probes into sapwood. Insertion of probes is time consuming and sensors must be airtight and completely water proof to avoid damage to the system. Although Green et al. [72] reported that the heat pulse sensors can produce accurate measurements of sapflow in plant stems, provided a reliable procedure is adopted, utmost care must be taken while installing these sensors due to their delicate nature and the high cost of the probes. TDP sensors are fragile and are prone to damage during high winds or storm periods. This was a major drawback and hindrance during this study as these sensors were broken due to bending of trees during wind, storm and cyclonic events. The breakage of sensor needles also resulted in short circuits and other technical problems. The needles in the HRM sensors are more robust and durable than those in the TDP sensors, yet there have been cases where the needles of the HRM sensors were bent by wind that affected stem movements. In open field experiments, especially in the landfill site, the wires connecting the sensor and the logger were damaged by rodents and/or birds. This caused malfunction of sensors on several occasions.

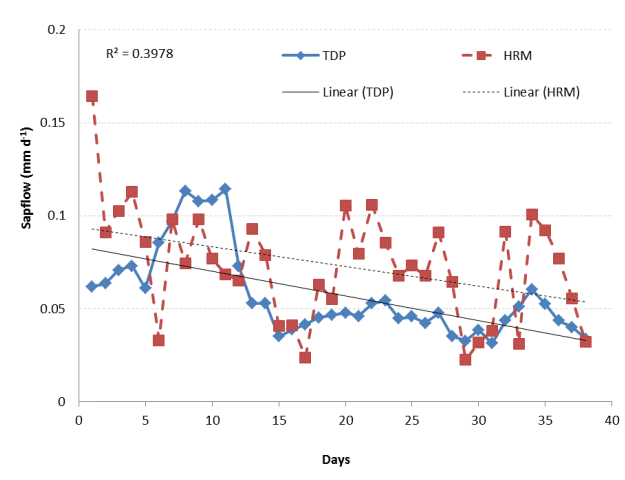

Figure 26: Comparison of TDP and HRM sensors for sapflow measurements recorded over 38 days.

\begin{tabular}{|l|l|l|l|l|l|l|}
\hline \multicolumn{2}{|l|}{ Sensor method } & \multicolumn{3}{|l|}{ Gravimetric method } & & \\
\hline $\begin{array}{l}\text { TDP } \\
\text { sensor }\end{array}$ & $\begin{array}{l}\text { Stem } \\
\text { girth } \\
(\mathrm{mm})\end{array}$ & $\begin{array}{l}\text { Sensor } \\
\text { reading } \\
\left(\mathrm{L} \mathrm{d}^{-1}\right)\end{array}$ & $\begin{array}{l}\text { Initial } \\
\text { weight } \\
(\mathrm{kg})\end{array}$ & $\begin{array}{l}\text { Weight } \\
\text { after } \\
\text { watering } \\
(\mathrm{kg})\end{array}$ & $\begin{array}{l}\text { Final } \\
\text { weight } \\
(\mathrm{kg})\end{array}$ & $\begin{array}{l}\text { Differenc } \\
{\mathrm{e}\left(\mathrm{L} \mathrm{d}^{-1}\right)}^{-1}\end{array}$ \\
\hline 1 & 84.66 & 8.5 & 292 & 320 & 312 & 8 \\
\hline 2 & 83.28 & 8.8 & 294 & 323 & 314.5 & 8.5 \\
\hline 3 & 891 & 9.3 & 296 & 324.5 & 314 & 9.1 \\
\hline
\end{tabular}

Table 4: Validation of sapflow readings obtained by TDP sensors.

\section{Conclusions}

Results from the current study demonstrate the ability of 15 native species to transpire in landfill conditions in addition to showing their adaptation to the seasonal variation in rainfall. The long-term sap flow monitoring data also show that the trees can remove up to $2.1 \mathrm{~mm} \mathrm{~d}-1$ (= $792 \mathrm{~mm}$ yr-1) of water and can survive on as low as $0.1 \mathrm{~mm} \mathrm{~d}-1$. Overall, the species differed significantly in their transpiration rates as expected; as they differ in various factors such as their growth rate, canopy structure, root depth and distribution. Transpiration rates of the tested species ranged between 0.9 to $2.1 \mathrm{~mm} \mathrm{~d}-1$, with an overall average of $1.4 \mathrm{~mm} \mathrm{~d}-1$. The TDP sensor data were verified by the gravimetric method. This short term test showed that the transpiration data from TDP sensors were comparable $(5 \mathrm{~mm} \mathrm{~d}-1)$ to those determined by the gravimetric method. This data and changes in soil moisture and increase in sap flow after rainfall events or irrigation clearly show that TDP data was reliable. Furthermore, values obtained from this study were similar to those reported by other researchers.

Diurnal variation in water uptake depends on VPD, which in turn depends on solar radiation, relative humidity and wind velocity. The species showed similar sapflow values as those reported by other researchers. Seasonal variation is an important factor and has not been clearly highlighted in this study due to lack of continuous monitoring and frequent technical interferences. However, in a few instances the same species has been continuously monitored, and these have demonstrated the ability of species to adapt to landfill conditions, where moisture supply may be excessive during certain seasons and deficient during other seasons.

The selected species also showed good responses to irrigation and rainfall events. The species increased transpiration rates within two hours of irrigation. Further research is needed to determine how species respond to variables such as water stress, temperature, wind velocity, light intensity and root depth and distribution, to determine the overall transpiration potential of a species in a phytocap or landfill.

In this study, transpiration had a positive correlation with tree height, DBH and D50. Other factors that influenced transpiration were rainfall, soil moisture availability, sapwood area and solar radiation. Transpiration data using TDP and HRM sensors revealed that the 3- 
year-old E. grandis transpired $2.5 \mathrm{~mm} \mathrm{~d}^{-1}$ with an average uptake of 1.9 $\mathrm{mm} \mathrm{d}^{-1}$ during the experiment, with the highest potential uptakes of up to $4 \mathrm{~mm} \mathrm{~d}^{-1}$. Sapflow of a given species varied significantly within the day and between different seasons and the transpiration rates also varied between trees of the same species.

Field experience suggests that TDP sensors are fragile and are prone to damage during high winds or storm periods. This was a major drawback and hindrance during this study as these sensors were broken due to bending of trees during wind and storm. Precautions are therefore needed to be taken while using these sensors. Tests indicated that sapflow readings recorded by TDP sensors are realistic and are comparable with each other and with those reported by other researchers. The high variability between species for water uptake and canopy interception offers an excellent opportunity to select best species for a given site to achieve an effective site water balance.

\section{References}

1. Weand BL, Horin JD, Hauser VL, Gimon DM, Gill MD, et al. (1999) Landfill covers for use at Air Force installations. Texas.

2. USDoE (2000) Alternative Landfill Cover. Sandi, New Mexico, U.S Department of Energy.

3. Eamus D, Hatton T, Cook P, Christine C (2006) Water relations of plants. Ecohydrology. Collingwood, Victoria, Australia, CSIRO Publishing.

4. Vose JM, Harvey GJ, Elliot KJ (2003) Measuring and modelling tree and stand level transpiration. Phytoremediation. In: McCutcheon SC, Schnoor JL (eds). Transformation and Control of Contaminants. John Wiley \& Sons, Inc.

5. Benyon RG (1999) Nighttime water use in an irrigated Eucalyptus grandis plantation. Tree Physiol 19: 853-859.

6. Cohen Y, Fuchs M, Green GC (1981) Improvement of the heat pulse method for determining sap flow in trees. Plant cell and Environment 4: 391-402.

7. Cleverly JR, Smith SD, Sala A, Devitt DA (1997) Invasive capacity of Tamarix ramosissima in a Mojave Desert floodplain: the role of drought. Oecologia 111: 12-18.

8. Hogg EH, Hurdle PA (1997) Sap flow in trembling aspen: implications for stomatal responses to vapor pressure deficit. Tree Physiol 17: 501-509.

9. Becker P (1998) Limitations of a compensation heat pulse velocity system at low sap flow: implications for measurements at night and in shaded trees. Tree Physiol 18: 177-184.

10. Oren R, Sperry JS, Ewers BE, Pataki DE, Phillips N, et al. (2001) Sensitivity of mean canopy stomatal conductance to vapour pressure deficit in flooded Taxodium distichum L. forest: hydraulic and nonhydraulic effects. Oecology 126: 21-29.

11. Assaf G, Zieslin N (1996) Night water consumption by rose plants. Journal of Horticultural Science 71: 673-678.

12. Donovan LA, Grisé DJ, West JB, Pappert RA, Alder NN, et al. (1999) Predawn disequilibrium between plant and soil water potentials in two cold desert shrubs. Oecologia 20: 209-217.

13. Lascève G, Leymarie J, Olney MA, Liscum E, Christie JM, et al. (1999) Arabidopsis contains atleast four independent blue-light-activated signal transduction pathways. Plant Physiology 120: 605-614.

14. Dye PJ (1996) Response of Eucalyptus grandis trees to soil water deficits. Tree Physiol 16: 233-238.

15. Kalma SJ, Thorburn PJ, Dunn GM (1998) A comparison of heat pulse and deuterium tracing techniques for estimating sap flow in Eucalyptus grandis trees. Tree Physiol 18: 697-705.

16. Soares JV, Almeida AC (2001) Modelling the Water balance of soil water fluxes in a fast growing eucalyptus plantation in Brazil. Journal of Hydrology 253: 130-147.
17. Benyon RG, Myers BJ, Theiveyanathan S (1996) Transpiration rates of effluent irrigated flooded gum and radiata pine plantations. Land Treatment Collective Annual Conference, NewZealand.

18. Clements FE, Martin EV (1934) EFFECT OF SOIL TEMPERATURE ON TRANSPIRATION IN HELIANTHUS ANNUUS. Plant Physiol 9: 619-630.

19. Forde BJ, Beardsell MF, Bassett HCM (1974) Comparative transpiration rates of three grass species. R Society New Xealand Bulletin 12: 417-421.

20. Kramer PJ (1969) Plant and soil water relationships: a modern synthesis, McGraw-Hill: New York.

21. Pruitt WO, Lourence FJ, Oettingen SV (1972) Water use by crops as affected by climate and plant factors. California Agriculture, pp: 10-14.

22. Bjorkman (1971) Comparative photosynthetic carbondioxide exchange in higher plants. Phototsynthesis and Photorespiration, Wiley Interscience: Ney York: 18-32.

23. Goldstein G, Andrade JA, Meinzer FC, Holbrook NM, Cavelier J, et al. (1998) Stem water storage and diurinal pattenrs of water use in tropical forest canopy trees. Plant Cell and Environment 21: 397-406.

24. Ryan MG, Bond BJ, Law BE, Hubbard RM, Woodruff D, et al. (2000) Transpiration of whole-tree conductance in ponderosa pine trees of different heights. Oecologia 124: 553-560.

25. Worledge D, Honeysett JL, White DA, Beadle CL, Hetherington SL (1998) Scheduling irrigation in plantations of Eucalyptus globulus and Eucalyptus nitens: a practical guide. Tasforests 10: 91-101.

26. Roberts S, Vertessy R, Grayson R (2001) Transpiration from Eucalyptus sieberi forests at different age. Forest Ecology and Management 143: 153-161.

27. Landsberg JJ (1997) Nitrogen Fixation in Trophical Forest Plantation. In: Nambiar EKS, Brown AG (eds.) Management of Soil, Nutrients and Water in Tropical Plantation Forests 43: 65-96.

28. Jarrell WM, Virginia RA (1990) Soil cation accumulation in mesquite woodland: sustained production and long term estimates of water use and nitrogen fixation. Journal of Arid Environment 18: 51-58.

29. Ansley RJ, Jacoby PW, Lawrence BK (1989) Influence of stress on water use patterns oh noney mesquite. Symposium on Shrub Ecophysiology and Biotechnology, Logan, Utah.

30. Ansley RJ, Jacoby PW, Cuomo GJ (1990) Water relations of honey mesquite following severing of lateral roots: influence of location and amount of subsurface water. Journal of Range management 43: 436-442.

31. Milne R, Deans JD, Ford ED, Jarvis PG, Leverenz J, et al. (1984) Comparison of two methods of estimating transpiration rates from Sitka spruce plantation. Boundary-Layer Meteorology 32: 155-172.

32. Allen RG, Pereira LS, Smith M (1998) Crop evapotranpiration: guidelines for computing crop water requirements, FAO irrigation and Drainage. Rome, Italy, Food and Agriculture Organisation of United Nations: Paper 56.

33. Weight JR (1971) Comparison of lysimeter and newtron evapotranspiration from semi-arid ragelands. Montana Agricultural Experiment Station, Journal Series 163.

34. Reicosky DC (1990) A portable chamber for evapotranspiration measurements and irrigation scheduling. Acta Horticulture 278: 455-461.

35. Hatton TJ, Moore SJ, Reece PH (1995) Estimating stand transpiration in a Eucalyptus populnea woodland with the heat pulse method: measurement errors and sampling strategies. Tree Physiol 15: 219-227.

36. Lundbland M, Lagergren F, Lindroth A (2001) Evaluation of heat balance and heat dissipation methods for sapflow measurements in pine and spruce. Ann For Sci 58: 625-638.

37. Saugier B, Granier A, Pontailler JY, Dufrêne E, Baldocchi DD (1997) Transpiration of a boreal pine forest measured by branch bag, sap flow and micrometeorological methods. Tree Physiol 17: 511-519.

38. Huber R, Fellner J, Doebrel G, Brunner PH (2002) Water flows of MSW landfills and implications for long term emissions. ISWA 2002 World Congress on appropriate environmental and solid waste management and technologies for developing Countries, Turkey. 
Citation: Venkatraman K, Ashwath N (2016) Transpiration in 15 Tree Species Grown on a Phytocapped Landfill Site. Hydrol Current Res 7: 236. doi:10.4172/2157-7587.1000236

Page 13 of 13

39. James SA, Clearwater MJ, Meinzer FC, Goldstein G (2002) Heat dissipation sensors of variable length for the measurement of sap flow in trees with deep sapwood. Tree Physiol 22: 277-283.

40. Belby T, Burgess SO, Adams AM (2004) A validation, comparison and error analysis of two heat pulse methods for measuring sap flow in Eucalyptus marginata saplings. Functional Plant Biology 31: 645-658.

41. Burgess SS, Adams MA, Turner NC, Beverly CR, Ong CK, et al. (2001) An improved heat pulse method to measure low and reverse rates of sap flow in woody plants. Tree Physiol 21: 589-598.

42. Vieweg GH, Zielger H (1960) Thermoelektrische registrierung der geschwindigkeit des transpirationsstromes. Ber. dt. bot. Ges 73: 221-226.

43. Braun P (1997) Sap flow measurements in fruit trees-Advantages and shortfalls of currently used systems. Acta Horticulture 1: 267-272.

44. Sakuratani T (1981) A heat balance method for measuring water flux in the stem of intact plants. Journal of Agricultural and Forest Meteorology 37: 9-17.

45. Velancogne C, Nasr Z (1989) Measuring sapflow in the stem of small trees by a heat balance method. HortScience 24: 383-385.

46. Weibel FP, Vos JA (1994) Transpiration measurements on apple trees with an improved stem heat balance method. Plant and Soil 166: 203-219.

47. Smith DM, Allen SJ (1996) Measurement of sap flow in plant stems. Journal of Experimental Botany 47: 1833-1844.

48. Marshall DC (1958) Measurement of Sap Flow in Conifers by Heat Transport. Plant Physiol 33: 385-396.

49. Nadezhdina N, Cermak J (2003) Instrumental methods for studies of structure and function of root systems of large trees. J Exp Bot 54: 1511-1521.

50. Whitehead D, Jarvis PG (1981) Coniferous forests and plantations. Water Deficit and Plant Growth. T. T. Kozwolski. New York, Academic Press 4: 50-152.

51. Wullschleger SD, Meinzer FC, Vertessy RA (1998) A review of wholeplant water use studies in tree. Tree Physiol 18: 499-512.

52. Nadezhdina N, Cermák J, Ceulemans R (2002) Radial patterns of sap flow in woody stems of dominant and understory species: scaling errors associated with positioning of sensors. Tree Physiol 22: 907-918.

53. Andrade JA, Meinzer FC, Goldstein G, Holbrook NM, Cavelier J, et al (1998) Regulation of water flux through trunks, branches and leaves in trees of a lowland tropical forest. Oecologia 115: 463-471.

54. Braun P, Schmid J (1999) Sap flow measurements in grapevines. Plant Soil 215: 47-55.

55. Granier A (1987) Evaluation of transpiration in a Douglas-fir stand by means of sap flow measurements. Tree Physiol 3: 309-320.

56. Lu P (1997) A direct method for estimating the average sap flux density using a modified granier measurement system. Australia Journal of Plant Physiology 24: 701-705.
57. Kucera J, Tatarinov FA (2003) Physical background of thermal methods of tree sap flow measurement. European Geophysical Society 5.

58. Tatarinov FA, Kucera J, Cienciala E (2005) The analysis of physical background of tree sap flow measurement based on thermal methods. Measurement Science and Technology 16: 1157-1169.

59. ICT International (2007) Citizen communications in crisis: anticipating a future of ICT-supported public participation. USA.

60. Sharma A (2008) Agroforestry systems for municipal effluent disposal. PhD Thesis. Central Queensland University, Rockhampton, Australia.

61. Collatz GJ, Ball JT, Grivet C, Berry JA (1991) Physiological and environmental regulation of stomatal conductance, photosynthesis and transpiration: a model that includes a laminar boundary layer. Agricultural and Forest Meteorology 54: 107-136.

62. Li Y, Fuchs M, Cohen Y, Wallach R (2002) Water uptake profile response of corn to soil moisture depletion. Plant, Cell and Environment 25: 491-500.

63. Katul G, Todd P, Pataki D, Kabala ZJ, Oren R (1997) Soil water depletion by oak trees and influence of root water uptake on moisture content spatial statistics. Water Resources Research 33: 611-623.

64. Zhao P, Rao X, Ma L, Cai X, Zeng X (2006) Responses of canopy stomatal conductance of Acacia mangium forest to environmental driving factors. Ying Yong Sheng Tai Xue Bao 17: 1149-1156.

65. Therakan PJ, Nowak CA, Abrahamson LP (2000) Modelling growth and biomass production in Willow plantation in the northeastern and midatlantic. Bioenergy USA.

66. Singh G, Bhati M (2003) Growth, biomass production and nutrient composition of Eucalyptus seedlings Irrigated with Municipal effluent in loamy sand soil of Indian desert. Journal of Plant Nutrition 26: 2469-2488.

67. Kammesheidt L, Dagang AA, Schwarzwaller W, Weidelt HJ (2003) Growth patterns of dipterocarps in treated and untreated plots. Forest Ecology and Management, pp. 174.

68. Herwitz SR, Slye RE, Turton SM (2000) Long-term survivorship and Canopy area dynamics of tropical rain forest canopy trees. Ecology 81: 585-597.

69. Grayson RB, Western AW, Chiew FHS, Bloschl G (1997) Preferred states in spatial soil moisture patterns: local and non-local controls. Water Resources Research 33: 2897-2908.

70. Olbrich BW (1991) The verification of the heat pulse technique for estimating sapflow in Eucalyptus grandis. Canadian Journal For Forest Research 21: 836-841.

71. Dunn GM, Connor DJ (1993) An analysis of sap flow in mountain ash (Eucalyptus regnans) forests of different age. Tree Physiol 13: 321-336.

72. Green S, Clothier B, Jardine B (2003) Theory and practical application of heat pulse to measure sap flow. Agronomics 95: 1371-1379. 